\title{
Bobot dan Panjang Saluran Pencernaan Sapi Jawa dan Sapi Peranakan Ongole di Brebes
}

\section{The Digestive Tract Organs Weight and Length of Java and Ongole Crossbred Bulls in Brebes}

\author{
E. Purbowati, E. Rianto, W. S. Dilaga, C. M. S. Lestari, dan R. Adiwinarti \\ Fakultas Peternakan dan Pertanian Universitas Diponegoro \\ Jl. Prof. H. Soedarto, SH Kampus Tembalang Semarang,50275 \\ e-mail: purbowati@hotmail.com \\ (Diterima: 15 November 2013; Disetujui: 6 Februari 2014)
}

\begin{abstract}
ABSTRAK
Penelitian bertujuan untuk memperoleh informasi bobot dan panjang saluran pencernaan sapi Jawa dan sapi PO. Materi penelitian berupa saluran pencernaan sapi Jawa dan PO jantan, masingmasing 6 buahdari RPH Brebes, Jawa Tengah. Hasil penelitian menunjukkan, bahwa bobot saluran pencernaan sapi Jawa $(11,61 \mathrm{~kg})$, terdiri dari lambung, usus halus, dan usus besar masing-masing 6,$21 ; 2,77$; dan 2,63kg. Bobot saluran pencernaaan sapi PO $(12,92 \mathrm{~kg})$, terdiri dari lambung, usus halus, dan usus besar masing-masing 7,44; 2,70; dan 2,78kg. Panjang usus total sapi Jawa 26,45m terdiri dari usus halus $20,52 \mathrm{~m}$ dan usus besar $5,93 \mathrm{~m}$, sedangkan sapi PO $30,69 \mathrm{~m}$ terdiri dari usus halus $23,36 \mathrm{~m}$ dan usus besar 7,33m. Kesimpulan penelitian ini adalah bobot saluran pencernaan sapi Jawa lebih rendah dari pada sapi PO. Panjang usus total sapi Jawa lebih pendek dari pada sapi PO.
\end{abstract}

Kata kunci : lambung, usus halus, usus besar, sapi Jawa, sapi PO

\section{ABSTRACT}

This study wanted to obtain information about weight and length of the digestive tract organs of Java and OC bulls. Twelve pieces of the digestive tract of Java and OC bulls were used in this experiment which was taken from Slaughter House in Brebes, Central Java. The results showed that the digestive tract weight of Java bulls about $11.61 \mathrm{~kg}$, consists of $6.21 \mathrm{~kg}$ stomach, $2.77 \mathrm{~kg}$ small intestine, and $2.63 \mathrm{~kg}$ large intestine (colon). The digestive tract weight of OC bulls about $12.92 \mathrm{~kg}$, consists of $7.44 \mathrm{~kg}$ stomach, $2.70 \mathrm{~kg}$ small intestine, and $2.78 \mathrm{~kg}$ colon. The length of total intestine of Java bulls $(26.45 \mathrm{~m})$ consists of $20.52 \mathrm{~m}$ small intestine and $5.93 \mathrm{~m}$ colon, while OC bulls $(30.69 \mathrm{~m})$ consists of $23.36 \mathrm{~m}$ small intestine and $7.33 \mathrm{~m}$ colon. It was concluded that the digestive tract weight of Java bulls lower than OC bulls and the total intestine length of Java bulls shorter than OC bulls.

Keywords : stomach, small intestine, colon, Java bulls, OC bulls

\section{PENDAHULUAN}

Keberhasilan program swasembada daging sapi pada tahun 2014 akan tercapai kalau seluruh sumber daya ternak di Indonesia dieksplorasi untuk dikembangkan. Salah satu kekayaan fauna yang dapat dieksplorasi untuk dikembangkan dalam mendukung program swasembada daging tersebut adalah sapi Jawa yang merupakan plasma nutfah Indonesia.
Sapi Jawa umumnya dipelihara secara tradisional dengan pakan seadanya, sehingga tidak terlihat potensinya sebagai ternak tipe pedaging.

Oleh karena itu banyak peternak yang beralih untuk memelihara bangsa sapi lain, seperti sapi Peranakan Ongole (PO), sapi Peranakan Simmental, dan sapi Peranakan Limousine. Hal ini mengakibatkan keberadaan sapi Jawa sebagai plasma nutfah Indonesia 
semakin terpinggirkan. Sapi Jawa dapat memperlihatkan produktivitas yang lebih baik dengan perbaikan jenis pakan yang diberikan. Purbowati et al. (2011a) melaporkan, bahwa sapi Jawa yang hanya diberi jerami padi dan dedak padi menghasilkan pertambahan bobot badan harian $(\mathrm{PBBH}) \quad 0,19 \mathrm{~kg}$, sedangkan yang diberi jerami padi, dedak padi, daun gliricidia, dan mineral dapat menghasilkan PBBH sebesar 0,63 kg. Lestari et al. (2012) melaporkan, bahwa sapi Jawa yang diberi konsentrat 30\% menghasilkan PBBH 0,44 kg, sedangkan yang diberi konsentrat $70 \%$ menghasilkan PBBH 0,64 kg. Hasil studi di RPH Brebes (Purbowati et al., 2011b), ratarata bobot potong sapi Jawa betina adalah 214,33 kg menghasilkan karkas sebesar 113,6 $\mathrm{kg}(52,41 \%$ dari bobot potong), yang terdiri dari tulang $0,47 \mathrm{~kg}(16,43 \%)$, daging $1,77 \mathrm{~kg}$ $(61,89 \%)$, dan lemak 0,62 kg (21,68\%).

Besarnya meat bone ratio (tanpa lemak) dan meat bone ratio (dengan lemak) sapi Jawa betina tersebut yaitu 3,16 dan 3,83. Produktivitas tersebut merupakan hasil akhir dari proses pencernaan pakan di dalam tubuh sapi. Kapasitas saluran pencernaan sapi perlu diketahui agar manajemen pemberian pakan dapat dilakukan dengan tepat. Namun informasi tentang kapasitas saluran pencernaan sapi, khususnya pada sapi Jawa masih jarang diperoleh, bahkan boleh dikatakan tidak ada. Informasi yang diperoleh dari penelitian ini akan menjadi dasar untuk melestarikan dan mengembangkan sapi Jawa, sebagai bangsa sapi lokal yang kompetitif.

Tujuan penelitian ini adalah untuk memperoleh informasi tentang kapasitas saluran pencernaan sapi Jawa dan sapi PO. Penelitian tentang kapasitas saluran pencernaan pada sapi Jawa, akan memberikan informasi dasar tentang kemampuan sapi Jawa tersebut dalam memanfaatkan pakan menjadi produk daging.

\section{METODE}

Materi penelitian berupa 12 buah saluran pencernaan yang terdiri atas 6 buah saluran pencernaan sapi Jawa jantan dan 6 buah saluran pencernaan $\mathrm{PO}$ jantan dari rumah potong hewan (RPH) di Brebes, Jawa Tengah, yang diambil secara incidental sampling. Kedua bangsa sapi yang digunakan mempunyai latar belakang pemeliharaan yang relatif sama yakni secara tradisional dengan pakan berupa rumput lapangan, jerami padi, dan jerami jagung, tanpa pemberian konsentrat. Kondisi gigi seri kedua bangsa sapi tersebut sudah berganti sepasang (poel 1).

Sebelum dipotong, sapi ditimbang bobot badannya. Kemudian saluran pencernaan diambil dan ditimbang. Setelah itu saluran pencernaan dipisahkan berdasarkan organnya yaitu lambung (rumen, retikulum, omasum dan abomasum), usus halus dan usus besar, dan masing-masing organ tersebut ditimbang. Isi masing-masing organ saluran pencernaan dikeluarkan dan ditimbang. Selanjutnya usus total diukur panjangnya, dipisahkan antara usus halus dan usus besar, kemudian masingmasing diukur panjangnya. Data yang diperoleh dianalisis dengan statistik sederhana dan deskriptif.

\section{HASIL DAN PEMBAHASAN}

Saluran pencernaan merupakan organ yang berperan penting dalam mengubah pakan yang diberikan untuk ternak sapi menjadi produk daging. Hasil penelitian bobot, isi dan ukuran saluran pencernaan disajikan pada Tabel 1, 2 dan 3 .

Hasil penelitian menunjukkan, bahwa bobot potong sapi Jawa jantan poel 1 (gigi seri sudah menjadi gigi tetap sebanyak 1 pasang) lebih rendah $(207,32 \mathrm{~kg})$ dari pada sapi PO jantan poel $1(241,86 \mathrm{~kg})$. Hal ini yang mengakibatkan bobot badan kosong dan bobot saluran pencernaan sapi Jawa (170,34 dan $11,61 \mathrm{~kg}$ ) juga lebih rendah dari pada sapi PO (203,36 dan 12,92 kg). Fitri (2010) menyatakan, bahwa hubungan antara bobot badan dan bobot tubuh kosong positif dan nyata dengan nilai $r=0,989$, sehingga bobot badan yang lebih tinggi akan menghasilkan bobot tubuh kosong yang lebih tinggi pula.

Ditinjau dari bobot organ saluran pencernaan, terlihat bahwa bobot lambung dan usus besar sapi Jawa $(6,21$ dan 2,63 kg) lebih rendah dari pada sapi PO (7,44 dan 2,78 kg), 
tetapi bobot usus halus sapi Jawa $(2,77 \mathrm{~kg})$ lebih tinggi dari pada sapi PO $(2,70 \mathrm{~kg})$. Dilihat dari proporsi bobot organ saluran pencernaan terhadap bobot badan kosong, ternyata persentase lambung antara sapi Jawa dan PO hampir sama, sedangkan persentase usus halus dan usus besar sapi Jawa lebih tinggi dari pada sapi PO. Hal ini karena bobot badan kosong sapi Jawa lebih rendah dari pada sapi PO. Demikian juga dengan proporsi bobot organ saluran pencernaan terhadap bobot saluran pencernaan total, persentase lambung sapi Jawa lebih rendah $(53,50 \%)$ dari pada sapi PO $(57,56 \%)$, tetapi persentase usus halus dan usus besar sapi Jawa lebih tinggi dari pada sapi PO.

Tabel 1. Bobot dan proporsi saluran pencernaan sapi Jawa dan PO Jantan Poel 1

\begin{tabular}{lrr}
\hline \multicolumn{1}{c}{ Parameter } & Sapi Jawa & Sapi PO \\
\hline Bobot badan (kg) & 207,32 & 241,86 \\
Bobot badan kosong (kg) & 170,34 & 203,36 \\
Bobot saluran pencernaan & 11,61 & 12,92 \\
total (kg) & & \\
$\begin{array}{l}\text { Bobot organ saluran pen- } \\
\text { cernaan (kg) }\end{array}$ & & \\
$\quad$ - Lambung & 6,21 & 7,44 \\
$\quad$ - Usus halus & 2,77 & 2,70 \\
$\quad$ - Usus besar & 2,63 & 2,78
\end{tabular}

Proporsi organ saluran pencernaan terhadap bobot badan kosong (\%)

- Lambung

- Usus halus

- Usus besar

Proporsi organ saluran pencernaan terhadap bobot saluran pencernaan total (\%)

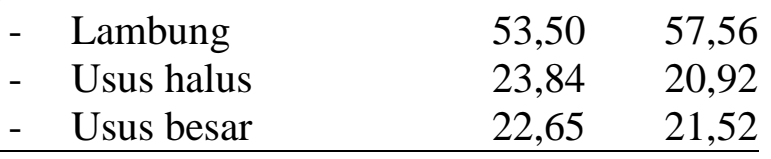

Kenaikan bobot usus halus disebabkan pertumbuhan usus dirangsang oleh serat kasar hijauan yang dikonsumsi, mengingat pakan yang diberikan pada sapi Jawa oleh peternak di Brebes umumnya adalah rumput dan jerami, maka usus sapi Jawa lebih tinggi dari pada sapi PO. Fungsi usus halus adalah dalam penyerapan nutrisi, sedangkan usus besar adalah penyerapan air, sekresi beberapa mineral seperti kalsium, tempat penampungan pakan yang tidak tercerna, dan fermentasi oleh bakteri.

Tabel 2. Bobot dan proporsi isi saluran pencernaan sapi Jawa dan PO Jantan Poel 1

\begin{tabular}{|c|c|c|}
\hline Parameter & Sapi Jawa & $\overline{\text { Sapi PO }}$ \\
\hline Bobot badan (kg) & 207,32 & 241,86 \\
\hline $\begin{array}{l}\text { Bobot isi saluran pen- } \\
\text { cernaan total }(\mathrm{kg})\end{array}$ & 36,98 & 38,50 \\
\hline $\begin{array}{l}\text { Proporsi isi saluran } \\
\text { pencernaan total } \\
\text { terhadap bobot badan } \\
(\%)\end{array}$ & 17,84 & 15,92 \\
\hline $\begin{array}{l}\text { Bobot isi organ saluran } \\
\text { pencernaan }(\mathrm{kg})\end{array}$ & & \\
\hline - $\quad$ Lambung & 31,46 & 33,23 \\
\hline - $\quad$ Usus halus & 3,32 & 3,09 \\
\hline Usus besar & 2,21 & 2,18 \\
\hline \multicolumn{3}{|l|}{$\begin{array}{l}\text { Proporsi isi organ } \\
\text { saluran pencernaan } \\
\text { terhadap bobot isi } \\
\text { saluran pencernaan total } \\
(\%)\end{array}$} \\
\hline Lambung & 85,06 & 86,31 \\
\hline Usus halus & 8,97 & 8,03 \\
\hline Usus besar & 5,96 & 5,65 \\
\hline
\end{tabular}

Tabel 3. Panjang dan proporsi panjang usus sapi Jawa dan POJantan Poel1

\begin{tabular}{lrr}
\hline \multicolumn{1}{c}{ Parameter } & Sapi Jawa & Sapi PO \\
\hline Bobot badan (kg) & 207,32 & 241,86 \\
Panjang usus total (m) & 26,45 & 30,69 \\
Panjang usus (m) & & \\
- Usus halus & 20,52 & 23,36 \\
- Usus besar & 5,93 & 7,33 \\
Proporsi panjang organ & & \\
usus terhadap panjang & & \\
usus total (\%) & & \\
$\quad$ - Usus halus & 77,59 & 76,12 \\
$\quad$ - Usus besar & 22,41 & 23,88 \\
\hline
\end{tabular}

Secara proporsional, persentase isi saluran pencernaan total terhadap bobot 
potong pada sapi Jawa $(17,84 \%)$ lebih tinggi dari pada sapi PO $(15,92 \%)$. Hal ini menunjukkan, bahwa kapasitas tampung saluran pencernaan sapi Jawa lebih tinggi dari pada sapi PO. Lestari et al. (2011) melaporkan bahwa konsumsi bahan kering (BK) sapi Jawa dan PO dengan pemeliharaan secara intensif tidak berbeda nyata $(\mathrm{P}>0,05)$ yaitu 2,09 dan $2,11 \%$ dari bobot badan. Hasil penelitian Adiwinarti et al. (2011) menunjukkan bahwa konsumsi BK sapi Jawa dengan pakan jerami padi dan konsentrat dengan level protein yang berbeda, tidak berbeda nyata $(\mathrm{P}>0,05)$ yaitu 2,57\% dari bobot badan. Sementara itu Rianto et al. (2005) melaporkan, bahwa konsumsi BK sapi PO dengan pakan rumput raja dan ampas bir sebesar 2,59\%. Purnomoadi et al. (2007) menyatakan bahwa sapi PO jantan yang diberi jerami padi $30 \%$ dan konsentrat $70 \%$ mampu mengkonsumsi BK sebesar 2,60\% dari bobot badan.

Bobot isi saluran pencernaan terbesar adalah pada lambung, baik pada sapi Jawa $(31,46 \mathrm{~kg})$, maupun pada sapi PO $(33,23 \mathrm{~kg})$, kemudian diikuti oleh isi usus halus dan isi usus besar. Bobot isi usus, baik usus halus maupun usus besar pada sapi Jawa lebih tinggi dari pada sapi PO. Hal ini yang mengakibatkan persentase isi usus halus dan isi usus besar terhadap isi saluran pencernaan total pada sapi Jawa lebih tinggi dari pada sapi PO. Lebih tingginya persentase isi saluran pencernaan sapi Jawa dibandingkan sapi PO, kemungkinan karena sapi Jawa dipelihara dengan cara tradisional yaitu siang digembalakan di hutan dan malam hari di kandangkan dan diberi pakan rumput ataupun jerami, sesuai dengan ketersediaan pakan yang ada (Lestari et al., 2009 dan Munadi, 2010). Owens dan Goetsch (1993) ; Lyford (1993) menyatakan, ukuran lambung ruminansia antara lain berhubungan dengan tipe pakannya. Owens dan Goetsch (1993) menyatakan bahwa volume rumen akan lebih besar bila pakan ternak mengandung lebih banyak pakan kasar.

Panjang usus total (Tabel 3) sapi Jawa $(26,45 \mathrm{~m})$ lebih rendah dari pada sapi PO (30,69 $\mathrm{m})$, demikian pula dengan panjang organ bagian usus (halus dan besar) yang lebih rendah pada sapi Jawa dari pada sapi PO. Namun secara proporsi, persentase usus halus sapi Jawa $(77,59 \%)$ lebih tinggi dari pada sapi PO (76,12\%). Soeharsono et al. (2010), menyatakan bahwa panjang usus halus, sekum, dan kolon sapi/kerbau masing-masing adalah 22,44 $\mathrm{m}(81 \%), 1,00 \mathrm{~m}(2 \%)$, dan 3,39 $\mathrm{m}(17 \%)$. Dibandingkan hasil penelitian tersebut, panjang usus halus sapi Jawa lebih rendah, tetapi panjang usus halus sapi PO lebih tinggi, dan panjang usus besar lebih tinggi baik pada sapi Jawa maupun sapi PO. Fitri (2010) melaporkan bahwa panjang usus halus sapi Jawa adalah 20,92 $\mathrm{m}$ dan usus besar adalah $6,17 \mathrm{~m}$, lebih panjang dari pada hasil penelitian ini, karena Fitri (2010) mengamati sapi Jawa jantan dan betina mulai belum poel hingga poel 4.

\section{KESIMPULAN}

Kesimpulan hasil penelitian ini adalah bobot saluran pencernaan sapi Jawa lebih rendah dari pada sapi PO. Saluran pencernaan sapi Jawa tersebut terdiri dari lambung $53,50 \%$, usus halus $23,84 \%$, dan usus besar $22,65 \%$, sehingga isi saluran pencernaan terbesar adalah lambung $85,06 \%$, kemudian usus halus $8,97 \%$, dan usus besar 5,96\%. Panjang usus total sapi Jawa lebih pendek dari pada sapi PO. Panjang usus halus dan usus besar sapi Jawa adalah 77,59 dan $22,41 \%$ dari panjang usus total.

\section{UCAPAN TERIMA KASIH}

Ucapan terima kasih disampaikan kepada Direktur Penelitian dan Pengabdian kepada Masyarakat, Direktorat Jenderal Pendidikan Tinggi (DP2M Ditjen Dikti) Kementerian Pendidikan Nasional yang telah membiayai penelitian ini melalui dana penelitian Hibah Fundamental pada tahun anggaran 2011, dengan DIPA Nomor: 0596/023-04.2-16/13/2011 tanggal 20 Desember 2010. Terima kasih pula kepada A.S. Suparno dan Yoga Hudoyo yang telah membantu dalam pengambilan data di lapangan. 


\section{DAFTAR PUSTAKA}

Fitri, N. 2010. Hubungan antara bobot badan dengan proporsi organ pencernaan Sapi Jawa pada berbagai umur. Fakultas Peternakan, Universitas Diponegoro, Semarang.

Lestari, C. M. S., A. T. Yulianika, E. Purbowati, R. Adiwinarti, M. Arifin, dan A. Purnomoadi. 2012. Produktivitas Sapi Jawa-Brebes (Jabres) dengan pakan jerami padi dan berbagai level konsentrat. Prosiding Seminar Nasional Berkelanjutan IV. Hal: 215-220. Fakultas Peternakan, Universitas Padjadjaran, Bandung.

Lestari, C. M. S., Soedarsono, A. Purnomoadi dan E. Pangestu. 2009. Status nutrisi Sapi Jawa yang dipelihara petani peternak Kecamatan Bandarharjo Kabupaten Brebes (studi pendahuluan). Prosiding Seminar Nasional Teknologi Peternakan dan Veteriner. Hal: 269-274. Pusat Penelitian dan Pengembangan Peternakan, Bogor.

Lyford, S. J., 1993. Growth and Development of the Ruminant Digestive System. In Church (Ed). The Ruminant Animal. Digestive, Physiology, and Nutrition. Waveland Press, Inc., Englewood Cliffs.

Munadi. 2010. Potensi dan alternatif pengembangan sapi Jawa khas Brebes (Jabres). Prosiding Seminar Nasional. Perspektif Pengembangan Agribisnis Peternakan di Indonesia. Hal.348-353 Fakultas Peternakan Universitas Jende ral Soedirman, Purwokerto. .

Owens, F. N. dan A. L. Goetsch. 1993. Ruminal Fermentation. In Church (Ed). The Ruminant Animal. Digestive, Physiology, and Nutrition. Waveland Press, Inc., Englewood Cliffs.

Purbowati, E., R. Adiwinarti, C. M. S. Lestari, E. Rianto, dan M. Arifin. 2011a. Live weight gain and feed cost per gain of Java Cattle with improved diet. The $3^{\text {rd }}$ International Conference on Sustainable Animal Agriculture for Developing Countries. School of Animal Production Technology, Suranaree University of Technology, Nakhon Ratchasima 3000, Thailand.

Purbowati, E., A. Purnomoadi, C. M. S. Lestari, dan Kamiyatun. 2011b. Karakteristik karkas Sapi Jawa (Studi Kasus di RPH Brebes Jawa Tengah). Prosiding Seminar Nasional Teknologi Peternakan dan Veteriner. Hal: 353-361. Pusat Penelitian dan Pengembangan Peternakan, Bogor.

Purnomoadi, A., B. C. Edy, R. Adiwinarti, dan E. Rianto. 2007. The performance and energy utilization of ongole crossbred cattle raised under two level supplementations of concentrate to the rice straw. Journal of the Ind Trop Animal Agric. 32 (1): $1-5$.

Rianto, E., A. S. Iswaldi, dan S. Dartosukarno. 2005. Penampilan produksi sapi PO dan PO Limousin yang mendapat pakan rumput raja dan ampas bir. Jurnal IlmuIlmu Perta. XX (2): 91-97. 